\title{
Seeking Coherence Among Member States: the Common European Asylum System
}

\author{
Elspeth GUILD*
}

\begin{abstract}
The objective of the CEAS is to create a common set of rules regarding asylum. The expectation was that a common set of rules would result in equivalent outcomes in the Member States. But, twenty years on, and in the third phase of legislative reform of the CEAS, differences in recognition rates continue to be enormous. This undermines the legitimacy of the whole CEAS project. But it is not the end of the problem, differential treatment of beneficiaries of international protection by different Member States is resulting in people being forced to move from one Member State where they have received protection to another and seek asylum again there because there are no integration conditions in the Member State which has (often reluctantly) ostensibly given them protection the content of which is empty.
\end{abstract}

Keywords: CEAS, solidarity, coherence, human rights

\section{(A) INTRODUCTION}

Competence to develop a Common European Asylum System (CEAS) was given to the EU in r999. 'The objective is to create a common set of rules regarding asylum including state responsibility for asylum applications, conditions of reception, receipt of applications and their determination as well as rights on receipt of either refugee status or subsidiary protection. The expectation was that a common set of rules would result in equivalent outcomes in the Member States. This is necessary to justify the CEAS rule that an asylum seeker only gets one consideration of his or her claim to protection within the whole of the EU. If the way in which the person is treated, and the claim determined is consistent then the outcomes should be more or less the same irrespective of the Member State which considers the application. But, twenty years on, and in the third phase of legislative reform of the CEAS, ${ }^{2}$ differences in recognition rates continue to be enormous. ${ }^{3}$ This undermines

a Article published on 31 December 2019

Jean Monnet Professor ad personam, Queen Mary University of London and Emeritus Professor, Radboud University Netherlands. This Chapter was written within the context of the research project 'The European Union's policies on asylum: confluences between the internal and the external dimensions' (DER2017-82/466-R), funded by the Spanish Ministry of Economy and Competitiveness and FEDER, as well as the Jean Monnet Chair EU Economic and Legal Integration for People, EAC/Ao3/2016 (2017-2020).

E. Guild, 'The Europeanisation of Europe's asylum policy', I8 (3-4) International Journal of Refugee Law (2016), at 63o-65ı.

S. Morgades-Gil, 'The Right to Benefit from an Effective Remedy against Decisions Implying the Return of Asylum-seekers to European Safe Countries: Changes in the Right to Appeal in the Context of the European Union's Dublin System vis-à-vis International and European Standards of Human Rights', I9 (3) European Journal of Migration and Law(2017), at 255-280.

3 According to the European Asylum Support Office Annual Report 2018 the country with the highest recognition rate in 2018 was Ireland $-86 \%$ and the lowest was the Czech Republic at $1 \%$. The countries of 
the legitimacy of the whole CEAS project. But it is not the end of the problem, differential treatment of beneficiaries of international protection by different Member States is resulting in people being forced to move from one Member State where they have received protection to another and seek asylum again there because there are no integration conditions in the Member State which has (often reluctantly) ostensibly given them protection the content of which is empty. In this contribution I will examine these challenges facing the EU regarding the CEAS.

\section{(B) COHERENCE IN THE CEAS}

The question of coherence in the CEAS is one of very substantial concern to all the EU institutions and the Member States. The arrival of more refugees than expected in 2015 2016 has brought to the surface a wide range of contradictions within the CEAS which care no longer possible to paper over. The biggest problem for people seeking international protection is finding somewhere safe for them and their families to live. Their residence will depend on what they are allowed to do and for how long and what services are made available to them to integrate into their new homes. Many beneficiaries of international protection may choose to return to this home states once the conditions which made the flee change. But many others will put down roots and become part of their new home society. The willingness of state authorities to engage actively and positively with people needing international protection varies from Member State to Member State but also, it is important to recognise, from one crisis in a country of origin to another. The media frequently castigates some Central and Eastern European Member States for the refusal to accept asylum seekers. Yet it is worth remembering that Poland has received approximately $1 / 2$ million Ukrainians a year since the 2014 annexation of Crimea by the Russian Federation. Many of these people are fleeing various kinds of violence but they are not encouraged to apply for asylum. Instead the Polish authorities issue them with (albeit temporary) work and residence permits and they are immediately encouraged to join the labour market. ${ }^{4}$ The EU institutions in the face of the Ukrainian crisis, followed suit and lifted the mandatory visa requirement in June 2017 for Ukrainians so that they can arrive regularly in the EU. The arrival of Ukrainians into the EU is not an issue for the CEAS at all. But the arrival of Syrians, Afghans and Iraqis has been and continues to be. In addition to measures to making arrival difficult (visa requirements,

origin are not substantially different - for a fuller analysis see E. Guild, 'Does the EU need a European migration and protection agency?' 28 (4) International Journal of Refugee Law (2016) at 585-6oo.

A. Grzymała-Kazłowska and A. Brzozowska, A., 'From Drifting to Anchoring. Capturing the Experience of Ukrainian Migrants in Poland', 6 (2) Central and Eastern European Migration Resiew (2017) Io3I22. 
carriers sanctions, etc. $)^{5}$ once on the EU's territory the operation of the CEAS and the limits of its coherence also create hurdles.

There are four main challenges to coherence within the CEAS. These are:

- Where are the asylum seekers? (the Dublin Regulation ${ }^{6}$ ) Under the Dublin Regulation, Member States determine where asylum seekers should make their applications. On the basis of these rules, the state which is responsible for the claim is also responsible for the care of the asylum seeker while the application is being considered. Further once the application is determined, that Member State is also responsible for the integration of the accepted refugees and the expulsion (in theory at least) of those rejected. This means that state authorities which do not invest sufficiently in asylum reception infrastructure to meet demand (like Greece or France) are unwilling to accept asylum applications preferring temporary deafness to asylum claims coupled with the hope that the absence of any support and both prohibitions on employment and heavy handed police action against foreign homeless persons will encourage people to 'move on'. ' The result is itinerant asylum seekers trying to find reception conditions somewhere.

- Whose responsibility are the asylum seekers? (the Dublin Regulation) As some states fail to invest in asylum support infrastructure, asylum seekers move elsewhere in search of conditions under which they will be able to make their asylum applications and stay safe and housed during the determination period. In order to deter asylum seekers from moving in search of dignity of reception, the CEAS includes the Eurodac database which holds the fingerprints of all asylum seekers (and persons who are apprehended irregularly crossing an external border). The purpose is to enable asylum authorities in any Member State to check the fingerprints of any asylum seeker before them to see whether their state is indeed responsible or whether the individual has been fingerprinted in another Member State in which case he or she should be the responsibility of that Member State. While in theory the list of grounds of responsibility of a Member State is long commencing with recognised family members (first degree only) in another Member State, in fact the main ground is the state through which the asylum seeker entered the EU. This is the ground which applies to most asylum seekers as if they had first degree family members they would arrive as family members (not as asylum seekers) or if they had visas or residence permits (another ground) they would be fixed in a Member State and not moving around. So, in fact the state of first entry is the default ground for state responsibility. This of course punishes

5 L. A. de Vries, and E. Guild, 'Seeking refuge in Europe: spaces of transit and the violence of migration management', 45 (12) Journal of ethnic and migration studies (2019) 2І56-2г66.

6 Council Regulation 604/2013, OJ 20I3 L I80/3I.

7 P. Bourbeau, P. 'Migration, resilience and security: Responses to new inflows of asylum seekers and migrants', 4I (2) Journal of Ethnic and Migration Studies at I958- I977; I. Kalpouzos, and I. Mann, I. 'Banal crimes against humanity: the case of asylum seekers in Greece', i6 Melb. J. Int'l L., (20I5) at I. 
Member States with long and uncertain external borders - such as Greece, Italy and Spain. Though there is nothing self evident about this. The Member State with the most uncertain external border is Cyprus with an international Green Line running down it. On one side the Turkish Cypriot government runs one part of the island without the benefit of international recognition (or EU membership). The other part of the island is an EU Member State and part of the CEAS but does not recognise the Turkish Cypriot authorities or the legitimacy of the dividing Green Line as a border at all. Yet the lack of a properly defined border and the possibility of 'massive' movement of Turkish or other third country nationals from the Turkish Cypriot side of the island to the EU Member State side has never been realised. Or if it has, it has never been recognised politically speaking. There are a sufficient number of political problems in urgent need of resolution in Cyprus that no one seems keen to engage in the politics of fear around migrants and asylum seekers. ${ }^{8}$ The Dublin system is baroque to say the least and does not work. ${ }^{9}$ According to the European Asylum Support Office (EASO) only about $3 \%$ of asylum seekers in the EU are ever actually subject to a Dublin transfer to another state. But that does not stop the fear of being 'Dublin-ed' being potent among asylum seekers. ${ }^{\text {io }}$ Though many alternatives to the Dublin system have been proposed over the years, some Member States seem wedded to the system and continue to try to find means to make it work, mainly by introducing more and more coercion into it."

- What are the outcomes of asylum procedures? (Qualification Directive ${ }^{\mathrm{I} 2}$ and Procedures Directive $\left.{ }^{\mathrm{i}^{3}}\right)$ : the EU has already adopted two phases of the Qualification Directive which sets out who qualifies for refugee status, closely following the UN Convention Relating to the State of Refugees rg5 and its r 967 Protocol and the Procedures Directive which establishes the common rules of the determination of asylum procedures and appeal rights. Neither measure is ideal according to refugee experts. ${ }^{14}$ However, they do provide a floor of rights and procedures which ought to result in some harmonisation. But as mentioned in the introduction, this has not led

8 C. Thorleifsson, 'Disposable strangers: far-right securitisation of forced migration in Hungary', 25 (3) Social Anthropology (2017) 3i8-334.

9 E. Guild, C. Costello, M. Garlick, V., Moreno-Lax, and S. Carrera, Enhancing the common European asylum system and alternatives to Dublin (Study for the European Parliament, LIBE Committee, 20I5).

ז K.M. Greenhill, 'Open arms behind barred doors: fear, hypocrisy and policy schizophrenia in the European migration crisis' 22 (3) European Law Journal, (2016) 317-332.

" E. Guild, C. Costello, and V. Moreno-Lax, Implementation of the 2015 Council Decisions Establishing Provisional Measures in the Area of International Protection for the Benefit of Italy and of Greece: Study (Policy Department: Citizens' Rights and Constitutional Affairs, European Parliament, 20I7).

12 Council Directive 20I1/95, OJ 20II, L 337/9-337/26.

13 Council Directive 2005/85, OJ 2005, L $326 / 13$.

14 S. Peers, 'EU Immigration and Asylum Law' in D. Patterson, and A. Södersten (eds), A Companion to European Union Law and International Law (Wiley Blackwell 20r6) 5r9-533; H. Dörig, I. Kraft, H., Storey, and H. Battjes, 'Asylum Qualification Directive 20II/95/EU' in K. Hailbronner, and D. Thym, EU Immigration and Asylum Law Nomos (Verlagsgesellschaft mbH \& Co. KG, 20г6) поо-г284. 
to great coherence in outcomes for asylum seekers across the Member States. While the average rate of protection (refugee status and subsidiary protection) is $37 \%$ across the EU, in fact the recognition rate varies. According to the European Asylum Support Office Annual Report 2018 the country with the highest recognition rate in 2018 was Ireland $-86 \%$ and the lowest was the Czech Republic at $1 \%$. The countries of origin are not substantially different. So it seems that common procedures and rights do not result in equal outcomes.

- What happens afterwards? Once a Member State makes a decision on an asylum claim, that is supposed to be the end of the story. For those who are granted protection, however, they are just as 'trapped' in the Member State which made the decision as they were while the application was being considered. There is no mutual recognition across the EU of positive decisions, even of those recognised as refugees under the UN Convention. So the refugee is required to remain in that one Member State. There is the possibility that after five years residence there if the refugee has worked and integrated sufficiently there that he or she may be granted long term residence status under the Directive ${ }^{\mathrm{r} \tilde{}}$ of that name which was extended to include refugees. At that point he or she will be able to move and reside in another Member State. ${ }^{16}$ In the meantime, if the refugee is within the Schengen zone, normally, the Member State which issued him or her a residence document on the basis of that status, has also notified that residence document as valid for short stays (9o days out of every i8o days) across the Schengen area. ${ }^{17}$ This means that a refugee can go on holiday within the 26 state zone to visit friends etc. But he or she must return to the state which recognised him or her after the go days. This is all rather theoretical as there are no systematic border controls on intra-Schengen movement (with some exceptions currently in place).$^{18}$ If a refugee stays longer this is not something which is obviously apparent to the authorities of the state where he or she is. That is so unless the refugee does something to come to the attention of those authorities, like make a further application for international protection. This is what happened in C-I63/I7 Jaxo - a case which came before the Court of Justice of the European Union. The relevant facts were as follows: Mr Jawo, a Ghanaian national, applied for asylum in Germany (2014); but in 20I4, before he went to Germany, Italy granted Mr Jaxyo a national humanitarian residence permit valid for one year. However, the grant of the residence permit in Italy meant that Mr Jaxio was no longer eligible for reception conditions in Italy and no integration measures were available. He ended up on the street with no assistance so

เ5 Council and Parliament Directive 20II/5I, OJ 20II, L I32/I.

${ }^{16}$ Other than Denmark, Ireland or the UK which do not participate in the Directive.

${ }^{7}$ E. Guild, E. Brouwer, K. Groenendijk, and S. Carrera, S., What is happening to the Schengen borders? (CEPS Paper in Liberty and Security in Europe 2015), at 86.

I8 T.D. Alkopher, and E. Blanc, E. 'Schengen area shaken: the impact of immigration-related threat perceptions on the European security community', 20 (3) Journal of international relations and development, (20I7) 5 II-542. 
he went to Germany and sought asylum again and was include in reception conditions there. A similar case in respect of a family granted subsidiary protection in Bulgaria and then moving to Germany came before the Court at about the same time $(\mathrm{C}-297 / 17$ Ibrahim \& ors (I9/03/I9)). The argument of Mr Jaxo and the Ibrahim family was that they must be entitled to make a fresh asylum claim as the conditions applicable as beneficiaries of humanitarian or subsidiary protection in Italy or Bulgaria constitute inhuman or degrading treatment contrary to Article 4 EU Charter of Fundamental Rights and Article 3 European Convention on Human Rights (ECHR). Although the Court was unsympathetic to various of their arguments (and those of the state - see below), the problem remains - what happens when after the grant of a protection status, the beneficiaries are refused further reception conditions under EU law and left to struggle on the street.

Outcomes of Asylum Applications: Eurostat 2018

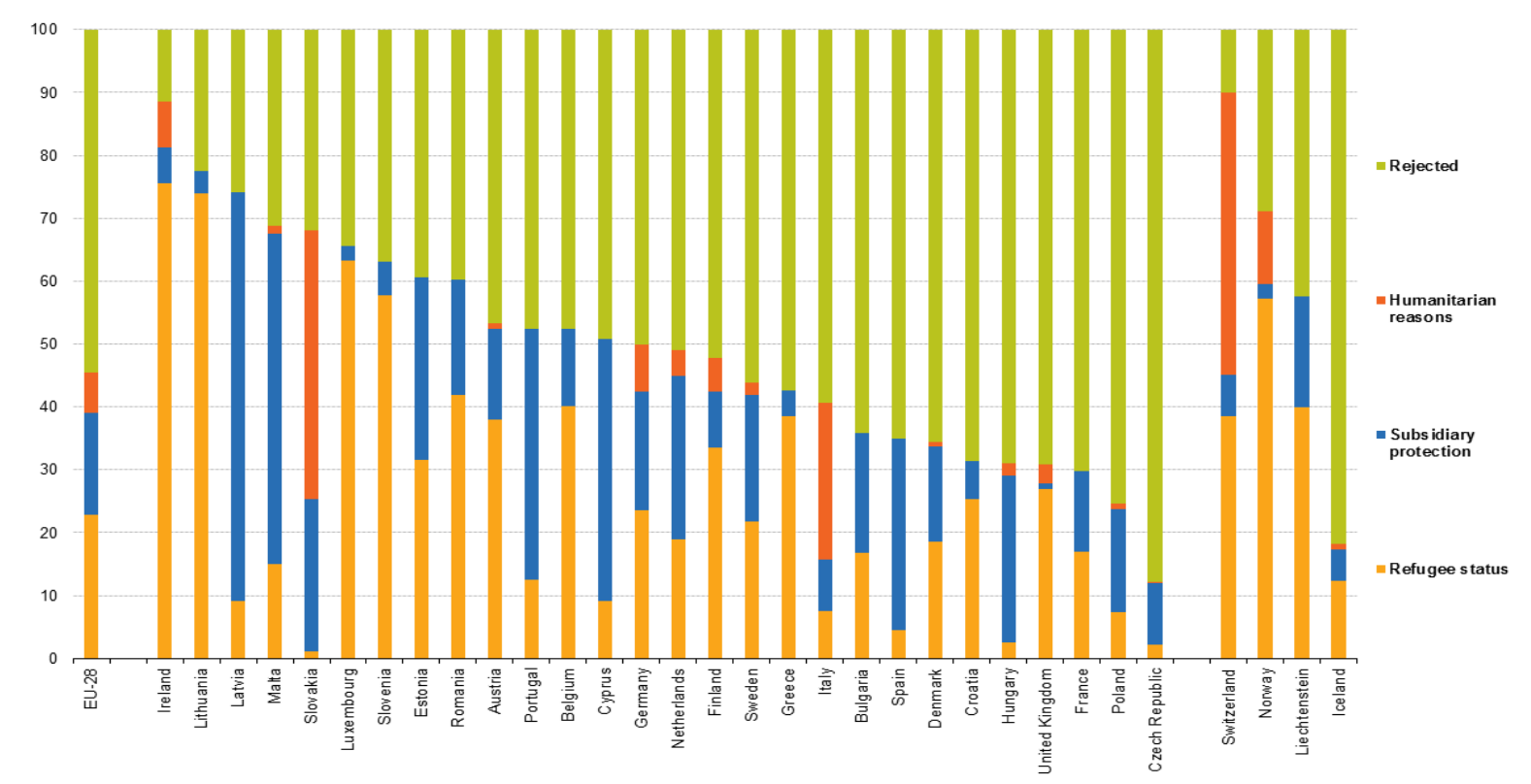

(C) SOLIDARITY IN THE CEAS

The 'big' idea as a solution to all the woes of the CEAS which policy makers have been working on since 2015 is what they call 'relocation'. But first the question of solidarity: according to Article 8o Treaty on the Function of the European Union 'The policies of the Union set out in this Chapter and their implementation shall be governed by the principle of solidarity and fair sharing of responsibility, including its financial implications, 
between the Member States. Whenever necessary, the acts of the Union adopted pursuant to this Chapter shall contain appropriate measures to give effect to this principle'.

There is little agreement among the Member States as to what exactly solidarity means but some of them, and in the institutions it is seen as a possible solution to many of the woes of the CEAS. But from the perspective of the asylum seeker the question is whether EU solidarity is going to be an engine of inclusion or exclusion. In 2016 the EU put into place an emergency (mandatory in part) relocation scheme for i6o, ooo Syrians (and others according to a calculation of recognition in the recent past) arriving in Greece and Italy. It was based on the Dublin Regulation and set out a complex relocation key on the basis of which all Member States were allocated a number of spaces which they were expected to make available relocation of asylum seekers from the two countries which considered themselves 'overloaded'. ${ }^{9}$ It was based on the principle of solidarity, though the Dublin Regulation is not a solidarity measure. A number of Member States were particularly exercised about the decision which was adopted by majority vote. Two of them challenged the direction before the Court of Justice (C-643/15 Slovakia \& Hungary v Council 6 September 20I7) on the basis that this was not a solidarity measure and that the mechanism chosen for adoption was unlawful. The challenge failed but on the ground that this was only an emergency measure as the Court held: 'Thus, in the circumstances of this case, there is no ground for complaining that the Council made a manifest error of assessment when it considered, in view of the particular urgency of the situation, that it had to take ... in the light of Article 80 TFEU and the principle of solidarity ... provisional measures imposing a binding relocation mechanism...' (para 253).

Accordingly, the Commission proposed a revised relocation system as part of the revision of the Dublin Regulation which at the time of writing is still before the institutions, though it is going nowhere fast. But the lessons from relocation are not entirely satisfactory from any perspective. The reality on the ground for people is not equivalent depending on where they were relocated and it is not clearly that they are remaining where they were sent. $^{20}$ As the Jaxo and Ibrahim scenarios reveal, between asylum seeker and refugee there may be systemic advantages to remaining an asylum seeker rather than being recognised as a beneficiary of international protection. When inequality extends beyond recognition and grant of status then for people, getting protection is unwelcome.

Returning then to the Jaxo decision, a number of challenges is evident immediately. First, the Court held that 'Each Member State shares with all the other Member States, and recognises that they share with it, a set of common values on which the European

${ }^{19}$ E. Thielemann, 'Why refugee burden-sharing initiatives fail: Public goods, free-riding and symbolic solidarity in the EU' 56 (I) Journal of Common Market Studies (2018) 63-82; A. Niemann and N. Zaun'EU refugee policies and politics in times of crisis: theoretical and empirical perspectives' 56 ( 1 , , Journal of Common Market Studies (2018) 3-22.

${ }^{20}$ S. Lavenex, "Failing Forward' Towards Which Europe? Organized Hypocrisy in the Common European Asylum System’ 56 (5) Journal of Common Market Studies (2018) п195-гі212. 
Union is founded, as stated in Article 2 TEU (para 8o);... The principle of mutual trust requires, particularly as regards the area of freedom, security and justice, each of those States, save in exceptional circumstances, to consider all the other Member States to be complying with EU law and particularly with the fundamental rights recognised by EU law' (para 8I). This is a good statement of how the treaties see Member States but the problem is that it does not necessarily correspond with how states treat people on the ground. As regards the problem of inhuman and degrading treatment the Court stated that ' $[\mathrm{I}] \mathrm{t}$ is immaterial, for the purposes of applying Article 4 of the Charter, whether it is at the very moment of the transfer, during the asylum procedure or following it that the person concerned would be exposed, because of his transfer to the Member State that is responsible within the meaning of the Dublin III Regulation, to a substantial risk of suffering inhuman or degrading treatment' (para 88). This is a more realistic recognition of the realities which people like Mr Jawo are facing. The finding is reinforced by the Court where it stated ' $[\mathrm{T}]$ hat [where a] particularly high level of severity is attained where the indifference of the authorities of a Member State would result in a person wholly dependent on State support finding himself, irrespective of his wishes and personal choices, in a situation of extreme material poverty that does not allow him to meet his most basic needs, such as, inter alia, food, personal hygiene and a place to live, and that undermines his physical or mental health or puts him in a state of degradation incompatible with human dignity' (para 92). This is a high standard which the Court is setting and it will have to be examined whether it is an interpretation of the Charter which is consistent with the European Court of Human Rights decisions on Article 3 ECHR and the treatment of asylum seekers or refugees. But the Court compounds the problem of coherence when it finds also that it is not necessarily a sufficient ground for a finding that an applicant for international protection would, in the event of transfer to another Member State, be faced with a situation of extreme material poverty. Instead the person must show the existence of exceptional circumstances that are unique to him or her and mean that if transferred he or she would be, because of his or her particular vulnerability, irrespective of his or her wishes and personal choices, in a situation of extreme material poverty after having been granted international protection. In effect the Court has found that only individual circumstances can justify stopping a return to another Member State under Article 4 Charter.

Yet, the Court accepts that the interpretation of Article 4 Charter must be consistent with the ECtHR's interpretation of Article 3 ECHR, where the subject matter comes within the scope of EU law. In 20I, the ECtHR had to decide an Article 3 claim by two men who had been refused asylum in the UK. The first, Mr Sufi, had arrived in the UK in 2003 and claimed asylum on three grounds: his membership of a minority clan, the claims persecution by a militia; the militia's killing of his father and sister and harm to him. His application was rejected on credibility grounds. The second, MrElmi, a member of the Isaaq clan in Somalia was granted asylum in the UK. But following serious criminal offence 
convictions his expulsion was ordered. They claimed before the ECtHR that would be at risk of ill-treatment if they were deported to Somalia. In the proceedings before the ECtHR the question arose whether the men had to show that their specific and individual circumstances had to reveal that they would be singled out for treatment contrary to Article 3ECHR. The Court held 'An applicant [does not need] to show the existence of special distinguishing features if he could otherwise show that the general situation of violence in the country of destination was of a sufficient level of intensity to create a real risk [re] Article $3 \ldots$ To insist in such cases that the applicant show the existence of such special distinguishing features would render the protection offered by Article 3...illusory. Moreover, such a finding would call into question the absolute nature of Article 3, which prohibits in absolute terms torture and inhuman or degrading treatment or punishment' (para. 2ı Sufi \& Elmi ECtHR 28/o6/ı).

Clearly between the two judgments there is space for concern. ${ }^{21}$ The question is how to resolve the apparent inconsistency. A number of approaches are possible which stretch from judicial rejection of inconsistency to resolving the problem for people on the ground. Among the options, as I see it are the following:

- The ECtHR could use the Bosphorus solution - that it will respect the EU legal order as providing equivalent human rights protection in the absence of evidence to the contrary. ${ }^{22}$ This would be a tacit acceptance that the EU should sort out the treatment of beneficiaries of international protection and that the Court of Justice's Jawo principle should be left an internal issue of equivalence; the level of violence in the Member States would be a matter for the Court of Justice even where that violence is destitution applicable to a small category of people - beneficiaries of international protection;

- The Court of Justice of the European Union could refine the 'singling out' requirement expressed in Jaxyo to ensure that it is consistent with the ECtHR's judgment in Sufi and Elmi; this would mean castigating Member States which do not provide for beneficiaries of international protection but also requiring other Member States to accept their applications - a form of solidarity with beneficiaries of international protection rather than between states;

- Leaving the field of the courts and their interpretations, clearly there is a problem on the ground. The EU legislator could think of ways to resolve the issue possibly by extending the Reception Conditions Directive ${ }^{23}$ to include post recognition stages

2. C. Costello, The Human Rights of Migrants and Refugees in European Law (Oxford University Press, 2015); J. Mink, 'EU Asylum Law and Human Rights Protection: Revisiting the Principle of Non-refoulement and the Prohibition of Torture and other forms of Ill-Treatment' I/(2), European Journal of Migration and Law (2012) пі9-і49.

22. C. Costello, 'The Bosphorus ruling of the European Court of Human Rights: Fundamental Rights and Blurred Boundaries in Europe' 6(I), Human Rights Law Review (2006) 87-130.

${ }_{23}$ European Parliament and Council Directive 2013/33/EU, OJ 2013 L I8o/96. 
while the beneficiary of international protection is receiving integration assistance to become self-reliant.

The reality on the ground is the problem - it seems that some Member States are unwilling or unable to provide post recognition or grant of status integration assistance to beneficiaries of international protection. So long as people with a protection status are not able to integrate and become self-reliant they need assistance. How long they will need assistance is indeed a matter of the specific situation of each person. While in some states the non-governmental sector is active providing such assistance, this is usually only possible with state financial support. What is key is that Member States must not tacitly drive out their refugees through the failure to provide integration conditions for them.

The issue of treatment of beneficiaries of international protection is only the latest step in dealing with coherence in the CEAS. There is nothing surprising or unexpected about the problem - it is inherent in a system which has developed in spite of the reluctance of some interior ministries to welcome asylum seekers and beneficiaries of international protection. Changing the paradigm around refugee protection may be the most productive way of ensuring solidarity. When political leaders and their ministries promote refugee protection as an opportunity for their states not a burden, the problematic practices will be easier to change ${ }^{24}$.

${ }^{24}$ V. Türk, and M. Garlick, M. 'From burdens and responsibilities to opportunities: the comprehensive refugee response framework and a global compact on refugees' 28 (4) International Journal of Refugee Law (2016) 656-678. 